\title{
Folkelighedsbegrebet i praksis \\ - en vandrelærers arbejde i 1920'ernes Sydslesvig
}

Af Anebine Danielsen

Begrebet »folkelighed « dukker op i utrolig mange sammenhænge; det indgår i beskrivelser af alt lige fra aldeles løssluppen feststemning til højtidelige ceremonier med stærke nationale undertoner. Også indenfor idrætten er det et ofte benyttet prædikat, og her fremstår det ligeledes som en temmelig bred betegnelse.

I det følgende vil jeg fortælle en del af en sydslesvigsk vandrelærers livshistorie og derigennem komme med et bud på, hvad man kunne kalde folkelighedsbegrebet i praksis.

Historien foregår i 1920'ernes Sydslesvig, og på trods af det semibiografiske udgangspunkt vil det være en fortælling, der kaster lys over samme periode og områdes »store « nationale historie.

En vigtig forudsætning for at forstå vandrelærer Jørgen Jørgensens arbejde er en bevidsthed om Sønderjyllands historie. Herudover vil forskellige aspekter af folkelighed og folkelig oplysning blive belyst.

\section{Historie}

I hertugdømmet Slesvig var indbyggerne i første halvdel af det 19. århundrede forholdsvis bevidste om deres tilhørsforhold. Trods modsætningerne mellem dansksprogede i nord og tysksprogede i syd opretholdt de en form for regional lokalpatriotisme. ${ }^{1}$ Men efterhånden som nationalis- men tændte i de fleste folkeslag i Europa, brød den sproglig-nationale modsætning ud i området. Den var medvirkende til borgerkrigen i 1848-50 og siden til krigen i 1864, hvor de danske styrker blev nedkæmpet ved Dybbøl, og Danmark mistede sine tre hertugdømmer - Slesvig, Holsten og Lauenburg. Hertugdømmerne havde på dette tidspunkt omtrent 1 mill. indbyggere, heraf levede næsten 400.000 i Slesvig. Af dem brugte ca. 170.000 dansk som omgangssprog, herudover var der 30.000 tosprogede. $^{2}$

Disse krige kom til at betyde en del for etableringen af den danske nationalstat. Danmark var i løbet af forholdsvis kort tid blevet et lille land uden store forskelle i befolkningen, hverken kulturelle eller sproglige. Samtidig følte mange, at sønderjyderne var blevet revet væk fra landet, og bevidstheden om især det tabte Slesvig var stor.

Historikeren Lorenz Rerup betegner det som en »fundamental fejlspekulation«, at Danmark fik så dårligt et resultat ud af forhandlingerne efter nederlaget i 1864. Han skriver bl.a.: »Også på den diplomatiske front tabtes krigen. Og den tabtes mere eftertrykkeligt end nødvendigt, fordi den danske regering og dens forhandlere forsmåede de spurve, som Londonkonferencen gav den $\mathrm{i}$ hånden, $\mathrm{i}$ håb $\mathrm{om}$, at mere krig ville give bedre resultater. $\aleph^{3}$

I dag kan vi se, at den »fundamentale 
fejlspekulation « på mange måder har styrket Danmark, idet udgangspunktet for den nationalstat, vi i dag er så stolte af, blev skabt ud fra situationen efter tabet af Slesvig. Ove Korsgaard kommer med en god pointe i den forbindelse: »...der [er] en indre logik $i$, at vi som nation ikke fejrer sejren i slaget ved Isted den 25. juli 1850 , men markerer nederlaget ved Dybbøl den 18. april 1864. Sejren havde ingen fremtid i sig. Det havde nederlaget. $\ll^{4}$

\section{Slesvig efter 1920}

Efter 1. verdenskrig fremlagde den danske regering og Vælgerforeningen (oprettet i 1888 ) et forslag om, at Sønderjyllands befolkning skulle stemme om deres nationale tilhørsforhold. Der blev lavet en zoneinddeling, og afstemningerne i februar og marts 1920 resulterede $i$, at 1 . zone (det nuværende Nordslesvig) stemte sig til Danmark, mens 2. zone (det nuværende Sydslesvig) stemte sig til Tyskland. ${ }^{5}$

Grænsen blev officielt meddelt Danmark d. 15. juni 1920. Og den 10. juli 1920 red Christian d. 10. over den gamle Kongeågrænse på sin hvide hest, mens statsminister Neergaard som taler ved en fest på Dybbøl d. 11. juli udtalte de berømte ord henvendt til de danske syd for grænsen: $»$ De skal ikke blive glemt. Det er en ærespligt for enhver regering at støtte dem og af yderste evne opretholde sprog og folkelighed, som de har ofret så tappert for. $\ll^{6}$

Det danske mindretal var et sindelagsmindretal, hvor sproget ikke var det altafgørende. Der kunne således være dansktalende tysksindede ligesåvel som tysktalende dansksindede. Det var endvidere et mindretal, der overvejende omfattede småkårsfolk (arbejdere, funktionærer, småhandlende og håndværkere), selvom de, der tegnede det udadtil, for en stor dels vedkommende var selvstændige erhvervsdrivende eller bønder. Det havde ikke mulighed for selv at finansiere sine aktiviter $\mathrm{i}$ nævneværdig grad og var således henvist til tilskud (danske og tyske statstilskud og private tilskud). Den største del af de private tilskud formidledes af Grænseforeningen, der blev oprettet i 1920 som en sammenfattende organisation for en lang række lokale sønderjyske foreninger i Danmark. $^{7}$

De danske skoler var en eksistensbetingelse for den danske folkedel. Den sidste danske skole var blevet lukket i Flensborg i 1878, og først i 1920 blev der her igen oprettet en dansksproget folkeskole. ${ }^{8}$

I 1926 udstedtes en preussisk skoleanordning, der tillod at oprette danske privatskoler med offentligt tilskud og påbød offentlige mindretalsskoler, når der var tale om mindst 24 børn. Den indeholdt nogle betingelser, som blev afskaffet med en ny skoleanordning i 1928, der indførte sindelagsprincippet om, at bekendelsen om at høre til mindretallet hverken må efterprøves eller bestrides. Dette skete af udenrigspolitiske hensyn til det tyske mindretal. ${ }^{9}$

\section{Folkelighed}

En vigtig del af den danske identitetsdannelse blev N. F. S. Grundtvigs (1783-1872) tanker, og det de førte med sig. Inspireret af den tyske kulturfilosof Johann Gottlieb v. Herder (1744-1803) beskæftigede Grundtvig sig meget med begrebet »folkelighed «, hvis væsentligste grundelementer bestod af det nationale og det kristne. Med Chr. Flor (1792-1875) blev Grundtvigs ideer om en dansk folkehøjskole omsat til praksis, og opførelsen af Rødding Højskole i 1844 var startskuddet til en omfattende højskolebevægelse. Den folkelige oplys- 
ning, der praktiseredes herfra, blev en aktiv del af den dansknationale sag, og højskolerne fik stor indflydelse på forskellige aktiviteter i samfundet.

Efter tabet af Slesvig kom Rødding Højskole til at ligge på tysk grund, og i stedet startede man i 1865 Askov Højskole lige nord for Kongeåen. Den blev snart den største og mest betydningsfulde af de grundtvigske vækkelsesskoler.

\section{Højskolefag}

Ifølge Ove Korsgaard blev to fag helt centrale for den nationale bevægelses selvforståelse, nemlig nationallitteratur og national historie. Det var her, man kunne dyrke modersmålet og fædrelandet: begreber, der var grundpillerne i den nye danske identitet. Højskolesangbogen kom til at spille en væsentlig rolle, men også Flors fortolkning af Grundtvigs historiesyn var et vægtigt grundlag for undervisningen.

Gymnastik og håndarbejde kom til at spille en afgørende rolle, men ikke som hovedfag, for »Kropsarbejde og håndarbejde havde ikke sproget som medium og kunne derfor ikke betragtes som egentlige åndsfag. $\ll{ }^{10}$

\section{Gymnastik}

For gymnastikkens vedkommende tilførtes der et ekstra aspekt, da den såkaldte svenske gymnastik blev indført i 1880'erne. Den blev hurtigt et utroligt vigtigt fag i den grundtvigske højskole. ${ }^{11}$ Det er tydeligt, at skiftet fra tysk til svensk gymnastik blev tillagt stor vægt, sikkert langt større end den faktiske forskel berettigede til. Igen har de nationale undertoner spillet kraftigt ind. Måske var den svenske gymnastiks største aktiv ligefrem, at den var ikke-tysk. Korsgaard refererer fra skiftet: »I en tale ved fremvisningen af den nye gymnastik og indvielsen af et nyt $\varnothing v e l s e s h u s$ formulerede Ernst Trier det ideologiske grundlag. Denne gymnastik skulle ikke bruges i en militær sags tjeneste, ej heller skulle den alene dyrkes for motionens skyld; den skulle derimod være et middel i folkeopdragelsens tjeneste. ${ }^{12}$

Ernst Trier var forstander på Vallekilde Højskole, og ifølge Korsgaard placerede han med sit syn på gymnastikken legems$\emptyset$ velserne næsten på linie med de centrale dannelsesfag (historie og litteratur). Dette var afgjort ikke i Grundtvigs ånd, idet han ikke tillagde de legemlige udfoldelser særlig stor vægt. Men ikke desto mindre tog mange grundtvigianere den svensklingske gymnastik til sig som en del af deres demokratiske og nationale bevægelse. ${ }^{13}$

Else Trangbæk gør opmærksom på, at den svenske gymnastiks indførelse i Danmark i høj grad var afhængig af den politiske situation i landet på det givne tidspunkt. Den blev således et udtryk for en modkultur mod højrekræfterne i skytteforeningerne og mod regeringen, i og med at den blev fremhævet som demokratisk. Dette var med til at gøre den svenske gymnastik til en del af landbobefolkningens politiske bevidsthed. ${ }^{14}$

Højskolemanden Jørgen Bukdahl (18971982) har også reflekteret over »det ekstra «, der var ved gymnastikken, altså det der gav en slags fællesfølelse ud over det rent sportslige. Bukdahl kalder det »punktet udenfor «, eller »Forstaaelsen af, at Sport og Idræt kun er et Led - stort eller lille, men et Led - i Ungdomsopdragelsen. « Og videre: »Det Punkt udenfor, der netop knyttede Gymnastikken som Led til en national Helhed, var det, man kalder det folkelige. Og saaledes har da Gymnastikken faaet fat paa flere unge i vort Land end noget andet, netop fordi den var knyttet sam- 
men med Interessen for Landets og Folkets Skæbne. $\ll^{15}$

Samme punkt forbinder han med genforeningshåbet, der var det, der kunne holde det fælles kold-grundtvigske grundlag samlet. ${ }^{16}$

I forhold til en anden problemstilling, vi skal se nærmere på senere, gør Bukdahl sig ligeledes nogle interessante tanker. Det drejer sig om sprogets betydning; i dette tilfælde om det er vigtigt at kunne tale dansk for at føle sig dansk. Bukdahls ord kan ikke umiddelbart opfattes som en bekræftelse heraf. Han koncentrerer sig i højere grad om ånden og det, man med et nutidigt begreb kunne kalde en slags flowtilstand. ${ }^{17}$ Han skriver: »Det bor i Sindelaget hos de unge, Iveren, Optagetheden, Forstaaelsen af, at man maa indordne sig i Holdet og Helheden for at blive fri i den Del, man selv er; Sangen, Koncentrationen og Selvforglemmelsen, Samletheden, hvor det bevidste og det ubevidste trækker i samme Retning o. s. v. Der kan være Aand i alt dette, selvom Ordet ikke lyder;...« ${ }^{18}$

\section{Skyttebevagelsen og delingsføreren}

I 1861 blev De danske Skytteforeninger oprettet. Dele af denne bevægelse blev stærkt optaget af Grundtvigs tanker og fik i det hele taget kraftige bindinger til højskoleverdenen. Det var også en slags samarbejde mellem skyttebevægelsen og højskolerne, der var grundlag for delingsførerbegrebet. Det var nemlig her, delingsførerne blev uddannet, og deres opgave blev at varetage gymnastikundervisning på frivillig basis. Korsgaard mener, at »'Den danske delingsfører' blev et moralsk begreb, hvis idealdannende betydning for den grundtvigske bondekultur vanskeligt kan overvurderes. $\ll^{19}$

Med det gamle delingsfører-ord $»$ Vil du tænde, må du brænde« som titel udgav
Gymnastik-Instruktørernes Landsforening i 1989 et jubilæumsskrift $i$ anledning af 100års fødselsdagen for stiftelsen af »Delingsførerforeningen af 1889 «. Forfatteren, John Engelbrecht, går på en meget engageret og også ret personlig måde i dybden med delingsførerbegrebet, hvilket nærmest resulterer i et glødende kampskrift fremfor en nøgtern, historisk fremstilling. Det er kaldstanken, der står som noget centralt for delingsføreren, og denne motivation kan ikke forklares rationelt og da slet ikke ud fra vore moderne livsværdier i dag. Engelbrechts skrift kan være med til at give en forståelse af, hvad der lå i delingsførerbegrebet, og hvordan det hang sammen med den tid, det opstod i. Han pointerer bl.a., at idealet var det hele menneske, hvor der var overensstemmelse mellem det indre og det ydre: »Den, der ikke ser sin livsgerning i idealets lys, mister retning og fortaber sansen til at orientere sig og ender i det holdningsløse. Den rette holdning er udtryk for, at den indre holdning har gennemtrængt den ydre. $\ll^{20}$

\section{Håndarbejde}

Også de håndværksmæssige højskolefag kom til at virke som led i den politiske ideologi. De aktiviteter, der blev udført, skulle være med til at indpode en national tankegang, hvilket ikke har været helt uden problemer: »Ikke alle [fag] var lige velegnede, nogle blev sorteret fra, idet de ikke var anvendelige $\mathrm{i}$ den nationale bevidstgørelsesproces, andre blev omformet til æstetiske aktiviteter med et folkeopdragende sigte. $\ll^{21}$ I håndarbejde kunne man brodere et bestemt mønster, der fremstod som et nationalt symbol. Et fag som sløjd blev for eksempel pludselig delt $\mathrm{i}$ to retninger, nemlig »dansk sløjd « og »Askov-Nääs sløjd «. Førstnævnte vandt især fremgang $\mathrm{i}$ byerne, mens sidstnævnte fik sit centrum i 
Askov og appellerede mest til landbefolkningen. Ernst Trier blev ifølge Korsgaard lige så begejstret for Nääs-sløjden som for Lings gymnastik. Der var stor overensstemmelse mellem pædagogikken i de to fag, og på Askov Højskole var sløjdlæreren og gymnastiklæreren i en årrække den samme person.

Som idealtypisk eksempel på, hvordan man brugte elementer fra almuekulturen til nationalpolitiske formål, nævner Korsgaard dansen. Han skriver: »Folkedans er noget andet end almuedans, idet den skulle udføres efter ganske bestemte pædagogiske og æstetiske forskrifter. Med overgangen fra almuedans til folkedans sker der både en nationalisering og en pædagogisering af dansen. Folkedans er en ren national konstruktion. $\ll^{22}$

Som nævnt var disse fag jo ikke åndsfag og dermed ikke de vigtigste i højskolen. Det var i hvert fald de mest fremtrædende højskolepersonligheder enige om, men om det rent praktisk måske var dem, der gjorde størst indtryk på eleverne, kan ikke vides. Den dag i dag er diskussionen om betydningen af de praktisk-æstetiske fag lyslevende, og at de har haft og stadig har en høj status blandt højskolernes brugere, er der ingen tvivl om.

\section{Vandrelarere}

Først og fremmest må det slås fast, at mindretallet - skønt affødt af en politisk bevægelse for tilslutning til Danmark - fra 1920 måtte lægge afgørende vægt på at fundere sig som en kulturel formation. ${ }^{23}$ Det var altså udgangspunktet for de sydslesvigske vandrelæreres virke, og derfor kom det folkelige fra starten af til at stå som det centrale.

Vandrelæreren var en person, der på en eller anden måde brændte for Slesvig og derfor ville yde en indsats - måske en hel livsgerning - for at arbejde for dansk sprog og kultur i det gamle, danske land. De første vandrelærere dukkede op i 1889, men allerede kort efter nederlaget i 1864 havde noget lignende fundet sted først og fremmest som privatlærere rundt omkring i danske hjem i Nordslesvig. Efterhånden begyndte forskellige foreninger at støtte lærernes arbejde $\varnothing$ konomisk, herunder Foreningen Dannebrog i København eller $»$ S.S. $\ll$ i Kolding. ${ }^{24}$ Fra starten var der mange problemer med de tyske myndigheder, eftersom de ikke ville tolerere privatundervisning på dansk. Det førte til udvisninger, uanmeldte bes $\emptyset \mathrm{g}$ og stadig kontrol, hvilket sikkert har afholdt mange fra at opsøge undervisningen. Vandrelærernes virksomhed måtte som følge heraf foregå i det stille, og udover de private foreninger kom der støtte fra Sprogforeningen (oprettet i 1880) og Skoleforeningen (oprettet i 1892). Officielt måtte lærerne ikke få penge for arbejdet, for så var det ulovligt, og derfor var det nødvendigt med et godt netværk, hvorfra man kunne organisere undervisningen.

Højskolerne fungerede som naturligt omdrejningspunkt for arbejdet i Slesvig, og vandrelærerne havde da også som regel et højskoleophold med sig som ballast.

Selvom vandrelærervirksomheden altså startede tidligt - og iøvrigt også blev en del af det tyske mindretal i Nordslesvig - er det i første række i historien om det danske mindretal i Sydslesvig efter 1920, at den for alvor kom til at udfolde sig. ${ }^{25} \mathrm{Og}$ det er da også den periode og det område, der vil blive behandlet i det følgende.

\section{Vandrelaerere i Sydslesvig efter 1920}

Efter afstemningsresultatet i 1920, hvor det blev klart, at Sydslesvig skulle forblive en del af Tyskland, blev der sat forskellige 
initiativer igang for at styrke det danske. Heriblandt også vandrelærerne. Det var naturligt, at det var Flensborg, der blev udgangspunktet, for det var her, langt størstedelen af de danske stemmer var afgivet. Da der ikke havde været danske skoler i Sydslesvig siden 1870 'erne, var en væsentlig del af mindretallet (som det jo nu for alvor var blevet) tysksproget. »Det nye danske mindretals kamp for at etablere sig og overleve blev derfor i første række en kamp for retten til skolegang på dansk «, skriver Bengtsson og Henningsen og tilføjer, at det tyske mindretal, der var opstået i Nordslesvig, selvsagt havde samme behov. Allerede i juni 1920 vedtog den danske Rigsdag en skolelov, som tilgodeså dette, samtidig med at den danske stat ydede store tilskud til tyske skoler. Sådan foregik det ikke i Sydslesvig. Selvom lovgrundlaget var til stede ${ }^{26}$, sørgede de lokale myndigheder for deres egen fortolkning af forordningerne, og det var sjældent til gavn for de danske. Som eksempel kan nævnes, at man i Flensborg få dage efter afstemningen meddelte, at man ville oprette en dansk kommuneskole. Der tilmeldtes ca. 1000 børn, men myndighederne indførte en sprogprøve, således at kun børn, der havde dansk som modersmål, kunne komme i betragtning. Herved blev under en tredjedel fundet egnet og resten afvist. I og med at det $\mathrm{i}$ så mange år havde været forbudt at undervise i »fremmedsprog « (heriblandt dansk), kan det virke lidt grotesk med det stillede sprogkrav. Det vigtigste for mindretallet var dog, at der blev mulighed for dansk skolegang i Flensborg. Sådan var det imidlertid ikke udenfor byen, idet alle ansøgninger blev afslået. ${ }^{27}$ Det var også derfor, at vandrelærernes vigtigste arbejdsopgaver kom til at ligge i landområderne. For nogle elever blev undervisningsproblemet løst ved, at de kom på efterskoler eller højskoler i Danmark, men heller ikke det var helt uden komplikationer. F.eks. kunne det være svært at integrere elever, der slet ikke talte dansk ved ankomsten.

Det var oftest de unge, der havde flest muligheder, især pga. deres mobilitet. For mange vandrelærere lå opgaven derfor $\mathrm{i}$ at undervise mindre børn og voksne, som ikke uden videre kunne forlade hjemegnen. Derudover lå der den vigtige opgave at skabe en følelse af samhørighed blandt de dansksindede. De tilhørte jo mange forskellige sociale lag, og det var ikke altid, at de havde andet tilfælles end lige det danske.

\section{Jorgen Jorgensen}

Jørgen Peder Jørgensen blev født på gården »Sølyst« på Store Magleby Fælled, Amager d. 18.12.1894. Om sine barneår på gården, hvor han voksede op som den ældste af fem søskende, skriver han: »Her har jeg faaet en meget streng Opdragelse i Tugt og Herrens Formaninger. Men det var ogsaa trange Tider, saa jeg maatte med ved Arbejde saa langt tilbage i Tiden, jeg husker; ja, jeg husker, jeg var med at tage Kartofler op, længe før jeg, liggende i Rækkerne, kunne se op over Kartoffeltoppene. $\ll^{28}$

Citatet stammer fra en stil med titlen »Benyttelsen af min Fritid «, som Jørgen Jørgensen skrev i 1923, da han var elev på Askov Højskole. Som det fremgår af titlen, skulle stilen handle om fritiden, men allerede på det tidspunkt var Jørgen Jørgensen så bevidst om det kald, han senere skulle følge, at han valgte at tilføje undertitlen: $»-$ selvbiografi indtil 1923 «. Dette viser med al tydelighed, at han ikke kunne skille fritiden fra livsgerningen, hvilket han også selv gør opmærksom på: »Fritidens Benyttelse er som en Kæde, der griber ind i mit 
hele Liv, og ingen af Leddene kan tages bort, uden at det hele falder fra hinanden. Det er Tildragelser fra Fritiden, der har præget mit Liv saaledes, at det har faaet en virkelig Fylde, ja, givet det et Indhold, som jeg ikke havde drømt om.« Der fortælles videre om en opvækst uden kammerater, idet gården lå et stykke fra nærmeste landsby, og drengene på de omkringliggende gårde var for store. Således blev marken og stranden, som hjemmet stødte op til, den vigtige ramme om drengeårene: »Naar undtages Skolegangen, var al min Fritid som Dreng henvist til dette Felt - helt isoleret fra Samkvem med andre Mennesker. Saaledes blev den lille Jørgen saadan en lille indadvendt en, som ingen Mennesker lagde Merke til. Lege Hest eller tage Del i andre Børnelege var jeg ikke meget for. Tilfreds var jeg, naar jeg fik lidt Tid for mig selv og kunne slentre ud over Marken eller ved Stranden. Her unders $\varnothing$ gte jeg Naturens Undere.«

Efterhånden som Jørgen blev ældre, gik han mere systematisk til værks. Nu begyndte han at notere sine iagttagelser, og her fremgår det, at det især var fuglene, der havde hans store interesse. Arbejdet var så grundigt, at det blev indleveret til den Skandinaviske Trækfuglekommision til videre bearbejdning. Alt tyder på, at Jørgen Jørgensen var blevet en ganske habil ornitolog, hvilket bragte ham ud af isolationen: »Gennem ornithologiske Udflugter kom jeg i Forbindelse med mange lærde Mennesker fra København; dette var som gav det mit Liv et helt andet Præg. Fra at have været en lille Særling, kom jeg nu i Kredse, jeg aldrig havde drømt om. Samfundsmæssige Problemer begyndte at røre sig i mit Indre, og mine kære Fugle maatte for en stor Del sættes i anden Række. Nu blev det Samfund og Folk, der skulde studeres, og politiske og nationale Problemer fæstnede sig i min Hjerne...«.
Da 1. verdenskrig udbrød i 1914, og der skulle oprettes et rekylkorps i St. Magleby, blev Jørgen Jørgensen korpsfører herfor han nævner selv, at det var, fordi han havde sine papirer i orden fra skydebanerne ${ }^{29}$, men hans nylig vakte interesse for det nationale har givetvis også spillet ind. Selvom det ikke blev til krig, betød disse år meget for Jørgen Jørgensen: »Jeg havde faaet Kammerater blandt mine Landsmænd og havde samtidig lært en Del af deres Særpræg at kende. Men ogsaa var det en Oplevelse i Tidens Spænding med min Gud, naar vi om Aftenen kunne slutte Øvelserne, naar Kl. var 9, og Kirkeklokkerne som vel nok de fleste Steder i Landet ringede til Gudstjeneste og Bøn. Da satte vi Gevær og Vaaben af anden Art ind i Vaabenhuset, og her oplevede jeg mange Møder med Gud.«

Tidligere i stilen havde Jørgen Jørgensen allerede givet udtryk for sit forhold til kristendommen: »Det blev for mig mangen Gang gennem Naturens store skrevne og uskrevne Bog en Oplevelse af Livet, ved gennem Tænkning at finde Vejene for Livets Love. Ogsaa naar sig kunne overføre disse Tanker paa Menneskets Liv, da var det, som jeg stod overfor noget stort, noget virkeligt, men ogsaa noget gaadefuldt; thi det Spørgsmaal stilledes mig mangen Gang, hvad der var bag det altsammen. Da fik jeg allerede i en ret tidlig Alder den Oplevelse virkeligt at se ind $\mathrm{i}$ det kristne Liv.«

Sammenhængen mellem natur og kristendom udmøntede sig hos Jørgen Jørgensen $\mathrm{i}$ ordenes bogstavelige forstand: hos ham blev det kristne naturligt, og selvom han sjældent betonede sin tro, kom den til at være en vigtig del af hans nationale og folkelige selvforståelse. Kristendommen var ikke noget, der kun foregik i kirken, det var - som hos Grundtvig - et evigt tilstedeværende livsgrundlag. Således var 
troen også tilstede i Jørgen Jørgensens senere livsgerning som del af det kald, han kom til at følge.

$\mathrm{Nu}$ var Jørgen Jørgensen for alvor kommet i søgelyset, og han blev opfordret til at redde den hensygnende ungdomsforening på Amager fra undergang (Amager konservative Ungdomsforening). Han ville ikke men følte det som sin pligt og endte med at sige ja. Det virkede i første omgang som en uoverskuelig opgave, da Jørgen Jørgensen aldrig havde været udenfor øens grænser og aldrig havde »holdt en ordentlig Tale«. Men med en systematisk fremgangsmåde båret frem af en meget stærk vilje gik han $\mathrm{i}$ gang. Som del heraf kan nævnes, at »Jeg studerede først mine Landsmænds Historie, merkede mig Ungdommens Trang og Lyster «. Der skal jo huskes på, at han var vokset op for sig selv, og da han endelig kom sammen med andre mennesker, var det lærde ornitologer, som ikke havde meget til fælles med landboungdommen. I højskolestilen opsummeres: »Hvad vi har gjort og ikke gjort gennem de 9 Aar, jeg var Formand, fatter jeg ikke rigtigt, men da jeg sidste Foraar forlod Amager, var der dog samlet en Kreds af god dansk Ungdom i ligesaa stort Tal af Karle og Piger, som der findes paa Askov Højskole i Vinter.« (På den udvidede skole, hvor Jørgen Jørgensen var elev, gik der i vinteren 1923-24 155 karle og 171 piger, altså ialt 326 ele$\operatorname{ver}^{30}$.

I 1915 blev Jørgen Jørgensen indkaldt til militærtjeneste, og han aftjente sin værnepligt som infanterist ved Aarhus Rekrutskole. Om tiden her foreligger ingen oplysninger, og det er således svært at vurdere, om interessen for Sønderjylland måske allerede er blevet vakt her. Det samme gælder for opholdet på Tune Landboskole i vinteren 1918-19, hvor Jørgen Jørgensen blev uddannet til landbrugskonsulent un- der forstander Niels Bredkjær. Men da mange landboskoler på det tidspunkt (og deriblandt Tune) havde et grundtvigsk idégrundlag, må man gå ud fra, at opholdet har givet Jørgen Jørgensen andet end landbrugsmæssig lærdom. Det var egentlig mod hans vilje at komme på landbrugsskole, men han gjorde det som noget naturligt, da han som den ældste søn jo skulle være landmand. Der var dog andet, der trak i ham: »Jeg havde imidlertid faaet en ny, aandelig Opvaagnen og var nu klar til at tage fat. Jeg fik ej heller hverken Fred eller Ro. Det gik fra Møde til Møde baade paa min Hjemegn, som i København. Sidstnævnte Sted var det navnlig de store sønderjydske Møder, der drog mig. Mangen Gang fandt jeg mig selv, egentlig uden rigtig at vide hvordan det var gaaet til, staaende paa Talerstolen, enten det saa var Spørgsmaal vedrørende Danmarks politiske Forhold eller vore Landsmænd Syd for Kongeaaen, det gjaldt.«

Af citatet fremgår det, at det ikke først og fremmest var Jørgen Jørgensens egen lyst og drivkraft, der styrede ham men en udefrakommende påvirkning. Den var ikke til at komme udenom; han følte sig kaldet til at arbejde for en bestemt sag. Man kan sammenligne det med det tidligere omtalte delingsførerbegreb, hvor kaldstanken også belystes. Det skal bemærkes, at alt tyder på, at Jørgen Jørgensen ikke havde nogen synderlig ballast med sig hjemmefra mht. de politiske diskussioner. Af de mange breve fra og til hjemmet, der er bevaret, drejer det sig udelukkende om beretninger og vurderinger fra Jørgen Jørgensens side, hvor breve fra forældre og søskende handler om landbrug, jagt og fælles bekendte, af og til med en kommentar om at Jørgen Jørgensen oplever mange spændende ting. 


\section{Sydslesvig-besøget}

Jørgen Jørgensen oplevede det som en meget stor skuffelse, da Sydslesvig ikke kom med til Danmark i 1920. Blandt ungdommen på Amager samlede man $2.000 \mathrm{kr}$. ind, som skulle bruges til en rejse for unge fra 2. zone. I oktober 1921 kom der således en flok på 21 unge sydslesvigere til Amager, hvor de blev indkvarteret på gårdene, og tiden gik med udflugter og møder. De blev vel modtaget alle vegne, selv Det Kongelige Teater gav fribillet til første parket, hvilket sikkert gjorde et stort indtryk på mange. »Mangen en ung og gammel havde Taarer i Øjnene, da Afskedens Time slog, og Toget rullede bort fra St. Magleby St., bort med en Ungdom, som havde haft en Oplevelse af det rigeste, de kunne tænke sig, og nu skulde de igen hjem, hjem under der grosse Vaterland, med Nøden og Elendigheden, Tvang og Tryk. «Ingen tvivl om at Jørgen Jørgensen syntes at grænsedragningen var uretfærdig. Videre skriver han: »Jeg maa for Skam melde, at disse Besøgsdage blev Fritid for mig, men saa vidt jeg erindrer, er det ogsaa de eneste Arbejdsdage i mit Liv, jeg har svigtet min Arbejdspligt for at udfylde Pligten for den Ungdom, der havde udset mig til dette Arbejdets Ledelse.« Jørgen Jørgensen arbejdede på dette tidspunkt som forvalter på sognerådsformand Dirch Dirchsens gård $\mathrm{i}$ St. Magleby, og det fremgår her, hvordan han er splittet mellem to forskellige »arbejdspligter «.

Der er meget, der tyder på, at Sydslesvig-besøget var afgørende for Jørgen Jørgensen og hans fremtidsplaner. Allerede få dage efter at de unge var taget fra Amager, skulle Jørgen Jørgensen til Kolding for at deltage i det konservative Landsrådsmøde. Efter mødet i Kolding rejste han alene videre mod syd fra den 17.-28.10.1921: »Jeg kom ved at køre i disse Egne til at tænke alvorligt, ved at køre i disse Egne, som for ikke længe siden havde været under tysk Herredømme. Allerede i Kolding blev man berørt af Sønderjyllands Nærhed. Fra Ruinerne af Koldinghus skuede man ned mod den gamle Grænse. Paa Slottet saa man Museet. I Anlæget staar en Mindesten med Lurblæseren som Relief. Han bærer Sværd ved Lænd. Indskriften lyder saaledes: »Slutter Kreds alle danske Mænd, Gud han raader, naar vi fange Sejr igen.« (...) Bygningsstilen vidner om Tiden, som Landet har maattet gennemgaa under tysk Styre. Gammel dansk Bygningsstil ved siden af grim tysk ser man.«

For Jørgen Jørgensen var den historiske sammenhæng uendelig vigtig for forståelsen af de nationale tanker, han gjorde sig. Det er bemærkelsesværdigt, så udførligt han i dagbøger og breve kan fortælle om historiske steder og mindesmærker. Vi ved, at han forlod skolen, da han som 14-årig blev konfirmeret for de næste mange år at arbejde som landmand hjemme på gården. Han tog på et tidspunkt nogle handels- og sprogkurser i København, men størstedelen af den historiske viden må have været selvlært.

I Sydslesvig brugte Jørgen Jørgensen dagene på at være sammen med de unge, han kendte fra besøget på Amager - alle 21 blev besøgt - og de gik rundt til en masse forskellige dansksindede i landområderne omkring Flensborg. Nogle dage besøgte han 5-6 forskellige hjem. En dagsberetning lyder f.eks.: »Kom til Middag til Gustav Lorenzens Hjem. Her var en Seminarieelev Hansen paa Besøg; han havde siste Vinter undervist de unge i Dansk om Aftenen og Børnene om Eftermiddagen. Da Tyskerne opdagede dette, kom der en Dag en Inspektør til den tyske Skole og spurgte, hvem det var, der om Eftermiddagen modtog Undervisning i den danske Skole. Først 
var der ingen, der turde sige noget; men saa rejste en lille Pige sig op og med hende 23 andre Børn. Saa var der kun 22 tilbage. Altsaa over Halvdelen gik til dansk Undervisning.

Efter Middag var vi en Tur ovre hos en ung Mand ved Navn Jacob Ertzinger. Derefter besøgte vi Chr. Meng. Han var ogsaa med paa Amagerturen. Her saa jeg en gammel Bedstemoder ved Rokken. Det var ellers et fattigt Hjem, men det var godt dansk. (...) Om Aftenen var jeg med Gustav Lorenzen til Bestyrelsesmøde hos Landmand Jørs, hvor Ungdomsforeningen Ydun havde Møde. (...) Her paa Lundtop er det Andreas Lorenzens Plan at bygge en dansk Skole. $\ll^{31}$

De fleste af aftenerne tilbragtes dog i private hjem, hvor der altid blev sunget danske sange, og nogle gange dansede de. Ofte blev Jørgen Jørgensen opfordret til at tale, og det skete også, at der blev talt »i oplysende Retning « til ham.

På turen kom Jørgen Jørgensen også i berøring med Tysklands fattigdom: »Vi gik ind paa en Kro for at faa os en Kop Kaffe. Det vi fik var nærmest at ligne med Opvadskervand. Kaffen vi fik paa Gaardene af brændt Rug var saa mange Fold bedre. Kager havde de ikke, dem maatte vi selv købe hos en Bager - Sukker, ja, en halv Teskefuld i smaa Skaale lignende Smaapigers Underkopper i Dukkek $\varnothing$ kkenet. « ${ }^{32}$

Også i hjemmene var der ofte fattigt, men det var jo også en kendsgerning, at mange af de dansksindede var trængt økonomisk. ${ }^{33}$ Således fik Jørgen Jørgensen på sin tur flere beretninger om, hvordan forskellige familier ikke turde vedkende sig deres danske sindelag af angst for at miste deres arbejde eller blive udstødt af lokalsamfundet.

Alt $\mathrm{i}$ alt blev turen utrolig begivenhedsrig for Jørgen Jørgensen, og han var over- bevist om, at dette kun var begyndelsen. Således skrev han i sin dagbog efter hjemkomsten: »Min første Sydslesvigrejse var endt.«

Som en slags opfølgning på turen sørgede Jørgen Jørgensen i julen 1921 gennem Amager Konservative Ungdomsforening for at indsamle ca. $100 \mathrm{kr}$., som blev sendt til Sydslesvig, så der kunne afholdes en stor, dansk julefest i Vesby Kro.

Der skulle gå over et år før Jørgen Jørgensen fik mulighed for at komme på sin anden Sydslesvig-rejse, men det skete så lige efter jul 1922. Denne gang boede han ikke privat, men i Flensborg. Han deltog i flere af de danskes julefester og kom derved til at hilse på mange nye mennesker. Bl.a. mødte han Niels Kjems, som senere kom til at spille en rolle for Jørgen Jørgensens ansættelse som vandrelærer. Han kom også ud til Strukstrup, hvor Lassens boede. Det var en af de mest fremtrædende familier i de dansksindede egne syd for Flensborg. Her havde unge tyskere tegnet stakitpælene blå, hvide, røde - de slesvigholstenske farver. Peter Lassen udtalte sig til fordel for Ejdergrænsen, og efter hans mening ville $85 \%$ af befolkningen så være fulgt med til Danmark. Den gamle Henrik Lassen på 83 år gav en stærk kritik af H. P. Hanssen (han mente, at han enten burde »klynges i Danmarks højeste Træ« eller »spærres inde i en Daarekiste $\left.\aleph^{34}\right)$. Besøget i Strukstrup viser både de konfrontationer, der var mellem danske og tyske, og ligeledes giver det et klart indtryk af, hvordan mange dansksindede i Sydslesvig følte sig svigtet af Danmark.

\section{Askov Højskole}

Den 3. november 1923 tog Jørgen Jørgensen til Askov Højskole for at være 6 måneder på 2. årgangs kursus og dernæst 
3 måneder på »Det udvidede Lærerkursus $\ll$.

Højskoleopholdet var et vigtigt led i forsøget på at løse den livsopgave, han havde påtaget sig. I selvbiografien skriver han: »(Jeg føler) at have min Plads, hvor et Pionerarbejde skal gøres for Kulturens Vækst blandt vore Landsmænd Syd for Grænsen. Ogsaa her fandt jeg min Begrænsning; thi med et saadant Arbejde følger en stor Pligt og for at faa forskellige Spørgsmaal klaret, er det jeg nu befinder mig paa Askov Højskole.«

Det er sikkert ikke tilfældigt, at Jørgen Jørgensen valgte Askov. I 1923 var det stadig en af de mest Sydslesvig-orienterede højskoler, med en solid, grundtvigsk ballast.

En dag var der til et »åbent hus-arrangement « (en form for studiekreds) hos en af lærerne diskussion af emnet »Er Menneskets Livs Handlinger frie eller Lovbundne $\ll$. Hertil skriver Jørgen Jørgensen i sin dagbog: »Et Menneske formes, som et Hvedekorn under Væksten, alt efter Vækst og Livsbetingelser - Fri Frihed bliver Tvang, medens Lovbunden Frihed bliver virkelig Frihed. « ${ }^{35}$ Citatet rummet i al sin enkelthed den livsindstilling, der gjorde det muligt for Jørgen Jørgensen at virke som vandrelærer i Sydslesvig de næste mange år.

At højskoleopholdet kun var et led i forberedelserne til Jørgen Jørgensens egentlige livsgerning lå altså hele tiden i baghovedet. Og da man på de grundtvigske skoler var meget optaget af grænselandet, var der også jævnligt arrangementer, der afspejlede denne tilknytning. F.eks. den 25.11.1923: »Kl. 5 talte Lærer Niels Kjems fra Harrislev om Skoleforholdene i Sydslesvig. Gymnastiksalen var fuld til sidste Plads - Om Aftenen var jeg med ovre hos Schrøders til et lille Møde hvor Kjems tal- te og gav en Mængde Oplysninger. $\ll^{36}$ Niels Kjems var af Dansk Skoleforening for Sydslesvig ansat som »rejsesekretær«, bl.a. med den opgave at organisere og lede vandrelærerarbejdet. Han var født i Hjortvad i Sønderjylland i 1888, og han valgte at optere for Tyskland (dvs. at bevare sit tyske statsborgerskab) for at opnå de bedst mulige vilkår for sit arbejde i Sydslesvig, hvortil han kom i 1922. ${ }^{37}$

Det er ligeledes værd at bemærke, at Jørgen Jørgensen allerede følte sig meget stærkt knyttet til grænselandet. Således samledes han med sønderjyderne, da de skulle forberede en dialektaften. Det er ikke til at tro, at han har deltaget, men han har følt sig som en af dem og har derfor villet overvære forberedelserne.

\section{Vandrelarerarbejdet}

I 1923, mens Jørgen Jørgensen er på et tomåneders ophold i Hamborg for at lære tysk, fortæller han $\mathrm{i}$ et brev til sin fader, hvad en vandrelærers opgave er: »Det vil sige, at jeg faar 2. eller 3. Byer med Kursus for Børn og Voksne 2. Aftener om Ugen i hver - Dernæst Foredrag om danske Forhold - Gymnastik - Sangleg-undervisning - Og for Landbrugets Vedkommende Foredrag om Landbrugsemner. $\ll^{38}$

Da han godt et år senere (1.11.1924) ankom til Sydslesvig, opsøgte han straks Niels Kjems i Harreslev, hvorefter han fandt sig et værelse i Flensborg. Allerede dagen efter var han til møde hos Kjems, hvor alle vandrelærerne var samlede for at modtage arbejdsplan for vinteren. Udover hr. og fru Kjems var de otte andre, heraf to ægtepar. De samledes igen dagen efter, hvor de fik undervisningsmateriale udleveret, og samme eftermiddag mødte Jørgen Jørgensen i Langbjerg, hvor han skulle undervise børn. I en beretning skrevet i foråret 1925 fortæl- 
ler han: »Samlingstedet var hos Arbejdsmand Wilhelm Barthelsen. Da jeg kom derud Kl. 3 var der kun mødt 3 Børn, hvad der saa meget trist ud. Jeg holdt dog Skole, men da jeg kom derud den 6 . November var det ikke bleven bedre, hvorfor jeg undersøgte Forholdene. Det viste sig, at Hjemmene var mangelfuldt underrettet, og desuden kom Børnene saa sent hjem fra Skole, at de ikke kunde møde igen Kl. 3. Næste Gang mødte vi først Kl. 3 1/2, og da var der mødt 12 B $\varnothing \mathbf{r n}$. Undervisningen foregik paa den Maade, at jeg lod Børnene synge dels af den lille røde Sangbog og dels af den blaa Sangbog. Nogen Danmarkshistorie fortalte jeg Børnene, hvilket Gang efter anden trak mange interessante Spørgsmaal frem. Til Læsning og Afskrivning anvendtes de dertil tildelte Bøger. Børnene maatte jeg dele i to Hold. Enkelte af Børnene naaede ret gode Resultater i Diktat- og Stilskrivning. Børnene gjorde sig Umage for Vinteren igennem at møde, men ofte maatte de hjælpe hjemme med Arbejde. Den største Fors $\varnothing$ mmelsesgrund for Pigerne var Pasning af smaa Søskende hjemme. $\ll^{39}$ Det refererede viser mange aspekter af arbejdet. For det første, at det var vandrelærerens opgave at sondere terrænet og finde ud af, om der i det hele taget var basis for undervisning. Men i og med at han var blevet ansat til at fungere i bestemte områder, måtte han gå ud fra dette. Hvis der så ikke var den store tilslutning, måtte han finde ud af hvorfor, og om det evt. kunne blive bedre. Man kan forestille sig, at det godt kunne være svært for en fremmed at begå sig korrekt og blive accepteret i de små lokalsamfund. Det gjaldt derfor i høj grad om at vinde folks fortrolighed. Når et hold endelig var blevet stablet på benene, kunne der opstå problemer på det faglige plan. Nogle har f.eks. været dygtige, mens andre har haft sværere ved det, de skulle lære. Det var ikke alle vandrelærere, der havde en læreruddannelse at støtte sig til (Jørgen Jørgensen havde jo også kun sine højskoleophold), og for dem har det været en ekstra stor udfordring at få skabt velfungerende hold. Ligeledes havde børnene først og fremmest deres tyske skole at passe, og de voksne havde deres arbejde; så det var nok ikke det danske kursus, der fik første prioritet i en materielt trængt tid.

Det var således en svær start for Jørgen Jørgensen som ud over sit børnehold i Langbjerg også havde et voksenhold samme sted. Tillige underviste han voksenhold i Hyllerup, Skovlund, Østerby og Valsbøl. Ifølge optegnelser over vinterarbejdet havde han hvert hold en gang om ugen i $2^{1} / 2$ time, dog mødte børneholdet to gange om ugen. At det var så forholdsvis lang tid hver gang skyldes selvfølgelig den lange transportvej og skulle vel også kompensere lidt for, at de ikke sås så tit. Ofte blev vandrelæreren og snakkede efter undervisningen, og lige så tit overnattede han rundt omkring på gårdene. Holdene i Langbjerg og Hyllerup undervistes i dansk, de andre steder stod der husflid på skemaet. Fælles var dog, at der altid blev sunget en del samt læst op. Deltagerantallet på holdene var alle steder mellem 10 og 12, hvilket svarer til en håndfuld danske familier hvert sted, da der altid var flere søskende. I betragtning af at undervisningen fandt sted rundt omkring hos private, kunne holdene vel heller ikke have været meget større. De steder, hvor tilslutningen var størst og mest stabil, blev der senere hen basis for at oprette danske skoler. Bengtsson og Henningsen påpeger, at vandrelærernes arbejde således i mange tilfælde har dannet grobunden for et mere stationært, dansk samlingssted i området. ${ }^{40}$

Midt i december 1924 var alle vandre- 
lærerne indbudt til et møde på Duborgskolen i Flensborg med Skoleforeningens bestyrelse. Her aflagde vandrelærerne beretning, og formanden for bestyrelsen gav dem bl.a. disse ord med på vejen: »... at Lærerne ikke blot maa være Lærere, men de maa ogsaa optræde som Organisatorer. De maa holde Forbindelse mellem Lærer og Hjem for at vække Interessen i Hjemmene, om at disse kan sende Børnene til dansk Kursus. $\ll^{41}$ Som opfølgning på mødet beretter Jørgen Jørgensen i sin dagbog en uges tid senere: »I Skovlund er der som Modtræk mod det danske Arbejde indrettet et godt Lokale i Skolen, hvor der holdes Foredrag eller undervises i Husflid. $\ll^{42}$

Disse tiltag var fra tysk side meget fornuftige. Hvor man ellers mest har hørt om chikane og besværliggørelse af de danskes arbejde, var dette et positivt modtræk, som ikke lagde op til strid og derfor heller ikke vakte kampånden på samme måde, som de negative tiltag gjorde. Samtidig kunne tyskerne opfange de familier, som var tvivlende og hidtil havde argumenteret med, at deres børn gerne skulle lære sproget, når de sendte dem til kursus i dansk regi. Og på samme måde kom husflid nu altså til at indgå som et led i den nationale kamp præcis som der blev lagt op til fra højskolernes side. Paula Jørgensen, Jørgen Jørgensens enke, har kunnet bekræfte, at f.eks. håndarbejdsmotiverne ofte var Dybbøl Mølle eller noget, hvor Dannebrog indgik. Dette har næppe været tilfældet i den tyske husflidsundervisning!

I det nye år fortsattes vandrelærergerningen, og af dagbogen fremgår det, at Jørgen Jørgensen nu mere fungerede som en del af de forskellige lokalområder, han »opererede« $i$. Han blev ofte inviteret med til fødselsdage, og begravelser deltog han også i. Ligeledes gav han gerne en hånd med ved landbrugsarbejdet, hvis han f.eks. havde overnattet på en gård efter undervisning aftenen $f ø r$.

Om det samlede forløb i vinteren 192425 skriver Jørgen Jørgensen: »Hvis jeg skal udtrykke min Mening over Vintren, som altfor hurtigt svandt hen, saa skal jeg først vedkende, at det ikke er de store Tal, vi har at fremvise. I Øjeblikket er det vist heller ikke saa meget Tallene, der skal spørges om, som om de Kredse der er, de staar sikre og rodfæstede. Helt rodfæstede kan de vel ikke være endnu, da vi endnu ikke er kommen langt nok bort fra de store Omvæltninger. Her har jeg dog det Indtryk, at i saa kort et Spand af Tid som Vintren, der gik, der mener jeg at kunne se og føle Kredsene stærkere. De enkelte Hjem begynder ogsaa at se det hele Arbejde paa et længere Sigt; hvorfor igen kommer til sin Ret de gamle Ord, »Det har slet ingen Hast for den som tror «. Der kan spørges: gaar det Skridt, der mærkes, fremad i social, aandelig eller national Retning. Hertil et baade og; thi først gennem et dansk-aandeligt og - socialt kan opleves et helt - nationalt Liv. Derfor ikke sagt, at andre ikke kan og skal kunne kaldes Danske. (...) Der er langt endnu hernede, men det skulde snart bære derhenimod, hvor ung og gammel samles ogsaa om de gamle kendte Ord, »Fædrejord og Fædrearv, værnes maa til egen Tarv «.«3

Her fremgår det klart, at Jørgen Jørgensens nationale sindelag var en del af en tænkemåde, hvor det nationale opfattedes som en naturlig og meget vigtig del af helheden. Om det så skal kaldes »punktet udenfor « eller blot en udpræget grundtvigsk tankegang betyder ikke så meget.

\section{Slesvig by}

I sommerperioden 1925, hvor vandrelærerne sædvanligvis holdt fri, blev Jørgen Jør- 
gensen i landsdelen for egen regning og fortsatte sit virke. Hans interesse begyndte mere og mere at samle sig om byen Slesvig, hvor det danske arbejde var langt mindre rodfæstet end i Flensborg-området. Han fik ordnet det således, at han skulle starte sløjd- og husflidsundervisning i Slesvig til efteråret sideløbende med sit arbejde i de nordligere landområder. Det fremgår af dagbøgerne, at der var rigeligt at se til i vinteren 1925-26, men Jørgen Jørgensen fandt en stor udfordring i at arbejde i de forholdsvis »uberørte « landområder omkring Slesvig by. Forholdene her var stærkt præget af politiske og personlige uoverensstemmelser, og det havde derfor stor betydning, at Jørgen Jørgensen vægtede det nationale og det folkelige højt. Derimod fors $ø$ gte han trods sit klare, politiske ståsted at være upolitisk i sit arbejde.

Han skriver selv i en beretning over »Kulturarbejdet i og omkring Slesvig gennem tre Maaneder« omkring årsskiftet 1925-26: »Angaaende Skolearbejdet i Slesvig By, saa har jeg nu siden Oktober (1925) med Forberedelser dertil i September holdt Husflidsskole en Gang om Ugen $i$ »Slesvighus«. (...) I denne Skole undervises der væsentlig i Kurvebinding og Træskæring, og nogle Deltagere har allerede vist virkelig gode Resultater - Saa vidt det er muligt, saa føres Samtalen paa det danske Sprog, og hver Aften synges der danske Sange. (...) Gymnastikken vil jeg søge ledet efter det bedste, som findes i Danmark og søge bragt den frem paa rette Plads. $\ll^{44}$

Her antydes, at Jørgen Jørgensen udmærket var klar over, hvor vigtig en del af den nationale identitetskamp gymnastikken var. Det havde den været både på dansk og tysk side siden anden halvdel af det 19. århundrede, hvor de europæiske nationalstater begyndte at tage form. ${ }^{45}$
Gymnastikken var, med Bukdahls ord, en del af en national helhed. Det var vandrelærerens $\varnothing$ vrige aktivitetsudbud selvfølgelig også, men der var alligevel en forskel. Styrken ved gymnastikken (og boldspil for den sags skyld) var holdfølelsen. Kroppenes aktive indsats, indrettet efter hinanden, gav en bestemt form for fællesskab, der gik længere end det sociale fællesskab, man havde ved f.eks. at sidde og flette peddigrør eller lave træskærerarbejder sammen.

I april 1926 flyttede Jørgen Jørgensen permanent til Slesvig by og kunne bruge al sin tid og energi her. Han forestillede sig, at det først og fremmest var ungdomsarbejde, han skulle beskæftige sig med, og i en foreløbig arbejdsplan for sommeren ridser han op, hvad arbejdet kommer til at indeholde. ${ }^{46}$ Han forestillede sig at lede boldspil både for unge mænd og kvinder (men selvfølgelig hvert sit hold), en ugentlig sanglege- og folkedanseaften, fællesudflugter til historiske eller natursk $\varnothing n n e$ steder, samling af den dansktalende ungdom, der har været på skoler i Danmark, udbringning af dansk litteratur på landet samt virke som landbrugskonsulent $i$ de sydlige egne. Hertil kommer, at han ville fortsætte sin husflidsundervisning og evt. starte et sløjdhold op. Der tilføjes, at han mest muligt vil benytte sin cykel, men at der også bliver nogle transportudgifter.

Planen kom nogenlunde til at holde stik, men Jørgen Jørgensen kommer også til at bruge megen tid på andre aktiviteter. Således påtager han sig at sortere og katalogisere alle bøgerne i den forholdsvis store bogsamling, der befandt sig i »Slesvighus «, de danskes mødested i byen. Herudover sprang han tit til, når redaktøren af »Der Schleswiger «, de danskes lokale avis, havde brug for assistance i forbindelse med sit journalistiske arbejde. 
I efteråret 1928 giftede Jørgen Jørgensen sig med Paula Hannberg, som kom fra et af de dansksindede (men tysktalende) hjem i Slesvig, hvilket yderligere knyttede ham til byen.

Bengtsson og Henningsen skriver, at sammenhængen mellem vandrelærervirksomhed og den senere fremvækst af danske skoler og forsamlingshuse i særlig grad er påfaldende for Jørgen Jørgensens vedkommende. ${ }^{47}$ Det var da også en stor dag for ham, da den første danske skole kunne indvies i Bismarcksgade i Slesvig den 16. oktober 1931. Allerede i løbet af sommeren 1930 var der blevet indrettet skolestue $\mathrm{i}$ de danskes lokaler i Langegade 33 (hvor avisen holdt til), samme sted som der havde været dansk børnehave siden $1928 .{ }^{48}$ Men nu havde man en bygning, der ikke kun skulle tjene som opholdssted for skoleelever men også være et synligt symbol på det fast forankrede danske arbejde i byen. Det var vigtigt, at byggestilen adskilte sig fra den tyske, og den dag i dag er det let at få øje på de danske skoler i Sydslesvig. De klassiske, røde murstensbygninger med hvide vinduer skulle på samme tid virke som en naturlig del af byen og samtidig skille sig ud.

På udposten Tønning ledte Jørgen Jørgensens arbejde frem til grundlæggelse af en dansk skole i $1935 .{ }^{49}$

Det var typisk for Jørgen Jørgensen, at han ikke havde ambitioner om at blive tilknyttet disse skoler nærmere. På trods af hans manglende læreruddannelse fik han forskellige tilbud, som han dog afslog. I stedet søgte han derud, hvor det danske arbejde endnu stod svagt for igen at bygge noget nyt op. Det var sådanne steder, han som pioner kunne gøre mest nytte, og det var den opgave, han var kaldet til - eller havde givet sig selv.

\section{Kontakten til Danmark}

At holde kontakten til Danmark var en vigtig faktor i Jørgen Jørgensens arbejde. Han mente således også, at det var af stor betydning, at sydslesvigske unge fik mulighed for et længerevarende ophold i moderlandet. Dette kunne enten være som feriebørn eller som elever på efter- eller højskoler. Begge dele brugte han megen tid på, og han har skaffet pladser til utallige børn og unge gennem årene.

\section{Feriebørn}

De feriebørn, der sendtes afsted, kunne ikke altid tale dansk, og det voldte en gang imellem problemer med værterne. Men for det meste var familierne i Danmark indstillet på, at de ville gøre en ekstra indsats for de børn, der kom, og det har ført til mange livslange forbindelser og venskaber. Omvendt kunne et enkelt barn »ødelægge « en plads, så de nægtede at stille sig til rådighed som værter fremover. Det var især, hvis der var blevet stjålet, eller opførslen var for dårlig. Også hvis børnene efter hjemkomsten ikke skrev takkebreve, kunne værterne føle sig krænkede. Her måtte Jørgen Jørgensen tit hjælpe til, og hørte han om børn, der ikke havde skrevet tak, måtte han tage ud til dem og sørge for, at det blev gjort. Det var altid et puslespil at få det til at gå op med pladserne, og ofte var det sådan, at de børn, der kom fra de mest belastede familier og derfor virkelig kunne trænge til at komme på ferie, var sværest at anbringe. Mange i Danmark fremsatte $\varnothing$ nsker om pæne og velopdragne børn, gerne med et godt, dansk sprog.

Det var forholdsvis mange børn, der kom på ferierejse hver sommer, og flest var der selvfølgelig fra Flensborg og omegn. Børnene fra Slesvig rejste gerne til Flens- 
borg om aftenen, og efter en overnatning dér fulgtes de så med den store transport nordpå. Jørgen Jørgensen sørgede for at få deres pas i orden og ledsagede dem til Flensborg. Sommeren 1923 fortæller han i et brev til hjemmet: »I Aften rejser Feriebørnene fra Slesvig til Danmark. Herfra alene skal over 100 med. $\ll^{50}$ Det var virkelig mange i betragtning af antallet af danske i byen.

\section{Efter-og højskoler}

For de lidt ældre unge arrangerede Jørgen Jørgensen ophold på efter- og højskoler. Her var det især af betydning, at de kunne få opholdet billigt, for ellers blev det for svært at søge tilskud. Via Jørgen Jørgensens ophold på Askov og Rønshoved havde han fået mange bekendtskaber i højskoleverdenen, og disse kontakter blev nu udnyttet flittigt. Således var der en del højskoler, der f.eks. gav $1 / 2$ friplads til sydslesvigske unge. Det var hovedsagelig piger, der kom afsted, vel fordi drengene enten skulle aftjene deres værnepligt eller hurtigst muligt komme igang med en uddannelse eller et arbejde. Ialt har der fra Sydslesvig i perioden 1920-1940 været 1300 unge på skole i Danmark. ${ }^{51}$

Jørgen Jørgensen sørgede for at vedligeholde sine forbindelser til højskolerne, dels ved jævnligt at tage nordpå, dels ved at invitere forskellige højskolefolk til Sydslesvig som foredragsholdere. Allerede i 1924 var Jørgine Abildgaard i Valsbøl for at vise lysbilleder fra nogle Finlandsture. Hun havde på det tidspunkt netop købt Snoghøj Højskole sammen med veninden Anna Krogh for at omdanne den til gymnastikhøjskole. Jørgen Jørgensen fik siden et godt forhold til de to kvindelige forstandere og sendte gerne elever til Snoghøj.

Aage Møller (fra Rønshoved Højskole) kom ligeledes til Sydslesvig for at holde gudstjeneste og foredrag.

På flere højskoler blev det tradition at foretage udflugter til grænselandet. Jørgen Jørgensen viste gerne rundt, når der kom elever til Slesvig, og han var ligeledes behjælpelig med at sørge for overnatning og andre praktiske ting. En dag i sommeren 1925 havde han høstet hø til et af sine landbrugsforsøg, men det afholdt ham ikke fra bagefter at tage til Danevirke og Slesvig med en stor flok piger fra Danebod Højskole. På vej hjem (til »Hjemmet« i Flensborg) havde han en pige foran på cyklen et stykke vej og reparerede to punkteringer. Om aftenen fortalte han dem om Slesvighus og dets historie. (Man må tænke på, at der er 40-45 km mellem Flensborg og Slesvig - og at vejstrækningen dengang var belagt med brosten eller grus!). Dagen efter deltog Danebodeleverne i morgensangen på Duborg-Skolen, hvor Jørgen Jørgensen også var med. Herefter besås forskellige danske institutioner, og »om Eftermiddagen var vi i Ansgar og paa Krigergraven, hvor vi sang Slumrer sødt i Slesvigs Jord. $\ll^{52}$ Det var altså national-historiske udflugter, højskolerne arrangerede, og gerne med nær kontakt til den dansksindede befolkning.

Sangen indtog helt efter grundtvigske traditioner en meget central plads i disse ture. Et typisk eksempel er et Danebod-besøg i 1926: »Modtog Kl. 11 Danebod-Højskoles Lærere og Elever, som kom paa Cykle fra Flensborg til Slesvig. Spiste sammen med dem. Jeg maatte fortælle lidt om Arbejdet hernede, baade i Flensborgs Landdistrikter og i Slesvig Kreds. Dernæst besøgte vi Domkirken, hvor vi sang »Dejlig er Jorden « - vi besøgte Valdemarsmuren, hvor jeg igen maatte fortælle. Vi sang »Danmark dejligst Vang og Vænge« og »I Danmark er jeg født«. Paa Halvkredsvol- 
den, hvor vi saa var, fortalte jeg lidt om dens Historie. Vi Sang »Der er et yndigt Land «. Over Slesvig cyklede Deltagerne saa hjem til Flensborg. $\ll^{53}$ Ud over det ideologiske indhold i sangene har selve den fælles aktivitet også haft stor betydning. Derfor blev sangen et vigtigt virkemiddel også for de danske i Sydslesvig, da de på den måde kunne markere deres nationale tilhørsforhold. Selv de, der ellers ikke beherskede sproget, kunne lære de mest brugte sange udenad og dermed føle sig som en vigtig del af det danske fællesskab.

I 1830'erne og 1840'erne udgav Grundtvig nogle skoleskrifter, hvori det klart fremgik, at han anså fællessangen for at være det vigtigste dannelsesmiddel - sangen havde for ham ligefrem kultisk karakter. ${ }^{54}$ Han skrev da også selv omkring 1500 salmer og sange, som var med til at danne grundlaget for den bestemte form for socialisering, der i en lang årrække fandt sted i grundtvigske kredse.

\section{Foreninger}

Den danske foreningstradition stod stærkt, da Jørgen Jørgensen kom til Sydslesvig, og han kom til at yde en stor indsats i dette regi. Ifølge Verner Bruhn er perioden fra 1870 frem til 1920 'erne af historikere ligefrem blevet kaldt foreningstiden. Videre skriver han: »Foreningerne var udtryk for mange forskellige interesser i samfundet, hvor mennesker ved at slutte sig sammen kunne fremme netop deres interesse, samtidig med at de gennem foreningen skabte et fællesskab om interessen. ${ }^{55}$ I Sydslesvig var det fællesskabet om det danske, der kom forud for interessen. Derved blev den selvforståelse, der opstod i forbindelse med foreningslivet, forstærket. Det var i foreningerne, at essensen af det folkelige blev præsenteret, hvilket understreges af
Jørgen Jørgensens præsentation af »Slesvig Ungdomsforening «: »Foreningens formålsparagraf var som et led i det danske, kristelige og kulturelle arbejde at samle ungdommen til oplysende foredrag, god underholdning, idræt, gymnastik og folkedans. $\ll^{56}$

Det følgende vil give et billede af foreningslivets mangfoldighed.

\section{Ydun}

Det var ungdommen, der havde Jørgen Jørgensens største interesse, og udover sin undervisning brugte han megen tid på foreningsarbejde om aftenen. Han var jo startet som vandrelærer i efteråret 1924, og allerede i januar 1925 blev han valgt til formand i ungdomsforeningen Ydun ved en generalforsamling på Østerbymark. ${ }^{57}$ Ugen efter deltog han i de sydslesvigske ungdomsforeningers sendemandsmøde i Flensborg.

Når der var møder i Ydun, foregik det f.eks. således: »Var om Aftenen til Ungdomsmøde i Skovlund i Foreningen Ydun, hvor jeg talte over Emnet Hjemstavnen. Vi sang en hel Del. Sanglege dansede vi i Tyksens Vognport til Kl. var 12 - Mødt var 22. $\aleph^{58}$ Eller: »Var om Eftermiddagen paa Østerby-Mark, hvor Ungdomsforeningen »Ydun « havde Sammenkomst - vi spillede Bold, legede Sanglege og sang nogle Sange. Da en Tordenbyge kom, læste jeg Jeppe Aakærs »Mens Pølsen koger «. $\ll^{59}$

Efter at Jørgen Jørgensen var flyttet til Slesvig, passede han stadig sit formandshverv i Ydun, men det kunne godt være drøjt: »Rejste om Morgenen over Flensborg til Østerby-Feld. Besøgte undervejs Siegmund Olsen og Worms i Skovlund samt Lorenz Jepsen i Valsbøl - var om Aftenen til Bestyrelsesmøde i Per's Pissel. Cyklede om Natten tilbage til Slesvig, hvor 
jeg efter 3 1/2 Time, Kl. 3 var. $\ll^{60}$ Derfor indså han også, at han ikke mere kunne overkomme det og ledede sidste gang $m \varnothing$ det til generalforsamlingen den 30.10.1926, hvor der valgtes en ny formand.

\section{Gymnastik og boldspil}

Som omtalt tidligere lå der langt mere i de kropslige aktiviteter, end det man umiddelbart kunne se. Fra det tyske mindretal i Nordslesvig foreligger der nogle meget klare tilkendegivelser om, hvor vigtigt det var at holde på de unge tysksindede også uden for skoletiden - og det gjordes bedst gennem ungdoms- og sportsforeningerne. ${ }^{61}$ Selve aktiviteternes indhold betød ikke så meget, det væsentlige var at tiltrække og holde fast på de unge, så de ikke meldte sig ind i danske eller såkaldt neutrale foreninger. Det var først, når de blev noget ældre, at man med held kunne appellere til f.eks. deres nationalfølelse og derved inddrage dem $i$ andre foreningsaktiviteter.

Helt så entydige erklæringer findes ikke fra Sydslesvig, hvor der jo også var den forskel, at idrætsaktiviteterne længe fungerede som et vigtigt samlingspunkt for de unge, der ikke havde en dansk skolegang til fælles. Desuden var der også det nationale idéindhold, som åbenbart stod stærkere hos de dansksindede idrætsudøvere end hos de tysksindede. En stor del af forklaringen herpå kan uden tvivl findes i de historiske forudsætninger, som er beskrevet indledningsvist.

For Jørgen Jørgensens vedkommende er det tydeligt, at han var glad for at overvære gymnastikopvisninger, der i høj grad tiltalte ham. Gymnasterne stod for noget folkeligt og nationalt, og det har givetvis været det, Jørgen Jørgensen godt kunne lide. En beretning fra »Sønderjyllands Gymnastik og Skyttestævne« vidner om, at gymna- stikken tidligt har været med til at rodfæste Jørgen Jørgensen i Sydslesvig. Han skriver: »Fra Padborg var vi 7 Sydslesvigere (med toget), da de optrædende hernede fra maatte blive hjemme, da Tyskerne nægtede os Fællesvisum. Det var en god Idrætsdag, skønt det regnede noget. « ${ }^{62}$ Bemærk at Jørgen Jørgensen kalder sig selv for sydslesviger, og dette var allerede i efteråret 1925 , altså kun knap et år efter at han var taget derned.

Jørgen Jørgensen var også forholdsvis hurtig til at starte boldspil op forskellige steder i Flensborgs landområder, og det samme gjorde han i Slesvig, da han kom dertil. Det fremgår af dagbogen, at han gik meget op i det sportslige, bl.a. beretter han fra et stævne i juni 1926: »Rejste sammen med Slesvigerne 80 Deltagere i 3 Lastauto til Ungdomsstævne i Hornskov. Vi kørte Kl. $12^{1 / 2}$ og var paa Pladsen lidt før $2^{1 / 2}-$ vore Spillere 2 Hold Nævebold 1 Hold Langbold og 1 Hold Piger i Nævebold spillede godt. Første Hold tabte mod Flensborg første. Andet Hold vandt over Flensborg andet. Langboldholdet vandt over Harreslev. Pigerne tabte mod Tarup. I Stafetløb vandt Harreslev over Slesvig - en fornøjelig Dag havde vi og en især god og munter Køretur hjem til Slesvig, hvor vi indtraf Kl. 11 - Vi hjembragte to Kranse til Slesvig (Egekranse med Dannebrogssløjfer). $\ll^{63}$

I vintermånederne 1926-27 havde Jørgen Jørgensen to hold i gymnastik, kvinder og mænd. Udover det tilegnede fra Askovopholdet havde han tidligere deltaget $i$ et instruktionskursus på Duborg-skolen og kendte i hvert fald noget til de førende stilarter i Danmark: »Hver Mandag Aften fra K1. 8 til 9 1/2 har jeg undervist et Kvindehold paa 10 Deltagere. Indtil Jul var det Gymnastik efter Ollerup System. Efter Jul gennemgik jeg et Kursus paa Snoghøj 
Gymnastikhøjskole, hvorefter dette System saa blev brugt, da det efter min Mening passer bedre for Kvinder, skønt Deltagerne var begejstrede for det andet.

Det andet Hold var et Mandshold paa 10 a. 12 Deltagere. Her undervistes efter System Niels Bukh. « ${ }^{64}$ Bemærkningen om, at de kvindelige deltagere var begejstrede for at gøre gymnastik efter Ollerup-systemet, er spændende. I Danmark tillagde mange på det tidspunkt forskellen på kvinde- og mandegymnastik stor betydning ${ }^{65}$, og det er tydeligt, at Jørgen Jørgensen er blevet påvirket heraf på det fulgte kursus. Snoghøj var kvindegymnastikkens højborg, hvor Niels Bukh i Ollerup var den mest markante skikkelse indenfor mandegymnastikken. Men de 10 sydslesvigske gymnaster vidste sandsynligvis ikke noget som helst om de forskellige gymnastiksystemer endsige de bagvedliggende ideologiske diskussioner. Derfor kunne de som kvinder »tillade « sig at være begejstrede for Niels Bukhs mandegymnastik. ${ }^{66}$ Det viser, hvor stor betydning det idéindhold, man tillægger forskellige aktiviteter, kan have.

Jørgen Jørgensen fortæller videre i sin beretning, at det er lykkedes at få gymnastikredskaber til Slesvig. Det er kommet i stand via »De sydslesvigske Ungdomsforeninger «, som har lånt redskaberne ud til slesvigerne.

Som en lille bibemærkning kan det nævnes, at det er karakteristisk, at boldspillet sagtens kunne ledes uden bestemte systemer eller forudgående kurser, mens gymnastikken krævede en form for uddannelse. Jørn Hansen skriver om forskellen: »Til at opretholde gymnastikkens idéelle ophøjede status havde man behov for uddannede ledere. Til opøvelsen i sportens processer kunne man nøjes med tranere, autodidakte eller uddannede. ${ }^{67}$ Gymnastikkens idéindhold henviser her bl.a. til det tidligere omtalte »punkt udenfor «, hvilket jo i allerhøjeste grad var tilstede i Jørgen Jørgensens aktiviteter - og i grænselandet gjaldt det vel både for gymnastikken $o g$ for boldspillet. Man må sige, at de givne nationale rammer gjorde det mere enkelt at tilføre de forskellige aktiviteter et overordnet folkeligt samlingspunkt næsten uanset indholdet.

\section{Perspektivering}

Med Jørgen Jørgensens vandrelærerarbejde har det vist sig, hvorledes det folkeligtnationale kunne være indeholdt i stort set alt. Allerede fra starten af det arbejde, der blev gjort for og blandt de danske syd for grænsen, var der protester mod den form, den folkelige indsats kunne have. Det var især de tysksindede, der mente, at danskerne »købte« sig til opbakningen ved bl.a. at udbyde populære aktiviteter som boldspil og håndarbejde. ${ }^{68}$ Denne problemstilling har fulgt det folkelige arbejde lige siden. Da Folkeligt Oplysnings Forbund stiftedes i Danmark i 1947, blev diskussionen også snart taget op der. På det første repræsentantskabsmøde i 1949 var det mest brændbare emne således peddigrør! Som idémæssigt forsvar for at inddrage peddigrør som fag blev et vers af Grundtvig trukket frem af stalden: ${ }^{69}$
Oplysning være skal vor lyst, er det så kun om sivet, men først og sidst med folkerøst, oplysningen om livet.

Det samme kom til at gøre sig gældende indenfor gymnastik- og idrætsverdenen, hvor det folkelige ikke længere var det før så oplagte punkt udenfor. I dag er diskussionen stadig lyslevende, f.eks. på højskoleområdet, hvor Oure Idrætshøjskole er 
det mest iøjnefaldende eksempel med deres store udbud af spændingsture og action-aktiviteter.

Siden genforeningen i 1920 har det nationale måttet finde nye linjer, og da det folkelige i så stor udstrækning var (og er?) forbundet med det nationale, er der opstået et tomrum, hvor en klar definition af et nyt og fyldestgørende indhold stadig savnes. Således er det nærmeste, vi i dag kommer et nationalt og folkeligt sammenhold, paradoksalt nok $\mathrm{i}$ forbindelse med fodboldlandsholdet. Netop en af de aktiviteter, som tidligere af mange blev kritiseret for ikke at være national eller folkelig nok ${ }^{70}$, er i dag gået hen og blevet symbol på de selvsamme begreber. Problemet er blot, at landsholdet er et flygtigt symbol med fare for at miste sin tiltrækningskraft i takt med dårlige præstationer. $\mathrm{Og}$ når hverken »håndboldpigerne« eller Bjarne Riis står klar i kulissen, er der ikke så meget tilbage at hænge folkeligheden op på i den forstand. Derfor er det vigtigt med andre tilgange til emnet.

I den forbindelse skal der her gribes fat $\mathrm{i}$ to bøger, der begge er skrevet af personer med langvarige og stærke bånd til det folkelige. Det drejer sig om Folkelighed og Fremtid (1990) af Johs. Stræde og Kundskabs-kaplфbet (1999) af Ove Korsgaard. Udgangspunktet er for begges vedkommende det moderne samfund og de deraf følgende udfordringer. Et af kendetegnene for det moderne er individualismen, som imidlertid bliver opfattet på helt forskellig vis af de to forfattere. For Stræde har fællesskabet stor betydning i forhold til det folkelige, hvorimod tanker om individualisering får ham til at beskæftige sig med fremmedgørelse, landets høje selvmordsprocent og upersonliggørelse. ${ }^{71}$ Korsgaard derimod vælger - inspireret af den tyske psykolog Thomas Ziehe, den tyske sociolog Ulrich
Beck og den engelske sociolog Anthony Giddens - at se individualiseringen (der ikke er det samme som individualisme) som en ny form for socialisering og altså ikke som et modbegreb til værdifællesskaber. ${ }^{72}$ Samtidig med at man frisættes fra gamle former for nationale, klassemæssige og familiemæssige bindinger, indgår man $\mathrm{i}$ nye former for institutionel afhængighed. Som Korsgaard skriver: »Det moderne individ lever under valgets tvang. Det er dømt til at vælge. Den enkeltes biografi er blevet en valgt biografi. « ${ }^{73}$ Jagten efter nye sociale tilhørsforhold betyder således også, at »det nationale spørgsmål« igen er på dagsordenen. Her gør Korsgaard opmærksom på den tvetydighed, at individualiseringen og globaliseringen ikke kun kan svække men også revitalisere følelsen af et nationalt tilhørsforhold. Det sidste eksemplificerer han med Undervisningsministeriets skrift »Strategi for udvikling af den internationale dimension i uddannelserne« (1997), hvis »egentlige formål« - ifølge Korsgaard - »med at inddrage den internationale dimension er at styrke elevernes nationale identitet. $\ll^{74}$ Det er tydeligt, at Korsgaard ikke bryder sig om den uddannelsespolitik. Han ser en fare i nationalismen med deraf følgende stigende fjendtlighed mod flygtninge og indvandrere. I stedet slår han til lyd for at udvikle nye måder at være dansker på: »...ved at se på den danske historie gennem en anden optik end den nationale, får vi materiale til nye fortællinger om det at være dansker. Gennem historien har vi nemlig været danskere på mange måder. I dag har vi for eksempel mulighed for at lære at være danskere på en kosmopolitisk måde. $\ll^{75}$

Citatet er ret interessant, idet man kan sige, at Korsgaard kommer med et forslag til en form for et nyt »punkt udenfor «, nemlig det kosmopolitiske. ${ }^{76}$ 
Johs. Stræde slutter også sin bog med et bud på en menneskeværdig udvikling. Han ender med at vende tilbage til det folkelige som den samlende fællesnævner: »Folkeligheden bliver således ikke bare en mulighed, men en nødvendighed for en menneskelig fremtid! «77

Begge forfattere er enige om, at vores historie er med til at give os baggrunden for at finde den rette vej frem. Det tankevækkende er, at Korsgaards løsning som den klart mest fremtidsorienterede henter sin inspiration fra tiden, før nationalstaten blev grundlagt. Han nævner det ikke direkte, men man kan ikke lade være med at tænke på helstaten og dens måde at fungere på.

Det interessante ved begrebet folkelighed er, at det opfattes så forskelligt og åbenbart - i hvert fald her i landet - ser ud til at være i stand til at »overleve « både det kristne og det nationale som en slags fællesnævner. Det kan hænge sammen med, at det folkelige lettere lader sig tilpasse individualiseringen end de to andre størrelser. I en artikel om »Det folkelige i en international tidsalder« skriver redaktør af Højskolebladet Niels Højlund: »Det folkelige har med selverkendelse at gøre, ikke med kvantitative størrelser som popularitet eller befolkning. ${ }^{78}$ Højlund indikerer, at selvom folkeligheden har en af historien bestemt skikkelse, så vil denne skikkelse stadig forandre sig. Man kan derfor ikke sige sig fri af sin folkelige sammenhæng.

»Folkeligheden er en ambition, en idealtilstand, en ide som man hele tiden prøver at indfange ${ }^{79}{ }^{79}$ skriver Lynge Kjeldsen, der er næstformand i DGI. Netop i Danmarks store idrætsforeninger har det folkelige været til diskussion adskillige gange. I Det skave tra ridser Verner Bruhn nogle af synspunkterne op, og det er symptomatisk, at der er så stor uenighed om, hvad det folkelige er og bør være - eller om det i det hele taget eksisterer længere. ${ }^{80}$ Det er nok derfor, at DGI's næstformand kommer med så ukonkret en definition af begrebet. Det folkelige er der hele tiden - og så alligevel ikke.

I dag er det ikke længere en selvfølge, at det kristne og det nationale er grundpillerne i det folkelige, og dermed som den samlende treenighed står bag alt - men sådan var det, da Jørgen Jørgensen arbejdede som vandrelærer i Sydslesvig i 1920’erne.

\section{Noter}

1. Lars N. Henningsen: »Die Zusammenführung Schleswigs unter dänischer Herrschaft - Idee oder Realität?« i: Henrik Becker-Christensen und Ulrich Lange (red.): Geschichte Schleswigs vom frühen Mittelalter bis 1920, Institut for grænseregions-forskning 1998, s. 68.

2. Lorenz Rerup: »Slesvig og Holsten efter 1830«, $i$ : Svend Ellehøj og Kristof Glamann (red.): Danmarks Historie, Politikens Forlag A/S 1982, s. 206-207.

3. Ibid., s. 206.

4. Ove Korsgaard: Kampen om lyset. Dansk voksenoplysning gennem 500 år, Gyldendal 1997, s. 162.

5. Her fra Rerup (1982), s. 347-348.

6. Her fra Rerup (1982), s. 347.

7. Se mere udførligt om Grænseforeningens dannelse i Johan Peter Noack: Det danske mindretal $i$ Sydslesvig 1920-1945, Institut for Grænseregions-forskning 1989, s. $97 \mathrm{ff}$.

8. Rerup (1982), s. 367.

9. Ibid., s. 368.

10. Korsgaard (1997), s. 218.

11. Ibid., s. 226.

12. Ibid., s. 226-27.

13. Ibid., s. 227.

14. Else Trangbæk: Mellem leg og disciplin, Bogforlaget DUO ApS 1987, s. 212.

15. Jørgen Bukdahl: Dansk Idrat (epilog), i: Kr. 
Krogshede (red.): Idrat. Vor Tids store Folke-opdrager, Odense 1943, s. 334-35.

16. Korsgaard (1997), s. 314.

17. Flow-begrebet beskrives udførligt af Mihaly Csikszentmihalyi i Flow, Munksgaard 1991.

18. Bukdahl (1943), s. 335.

19. Korsgaard (1997), s. 227.

20. John Engelbrecht: Vil du tande, må du brande... Gymnastik-Instruktørernes Landsforening 1989, s. 11.

21. Korsgaard (1997), s. 228.

22. Ibid.

23. Noack (1989), s. 533.

24. Allan Bengtsson og Lars N. Henningsen: Vandrelarere, rejsende $i$ dansk kultur. Studieafdelingen ved Dansk Centralbibliotek for Sydslesvig 1996, s. 14.

25. Ibid., s. 7.

26. Bengtsson og Henningsen (1996) refererer på s. 37 fra Weimarforfatningen af 11 . august 1919, artikel 113: »Die fremdsprachigen Volksteile des Reichs dürfen durch die Gesetzgebung und Verwaltung nicht in ihrer freien, volkstümlichen Entwicklung, besonders nicht im Gebrauch ihrer Muttersprache beim Unterricht sowie bei der inneren Verwaltung und der Rechtspflege beeinträchtigt werden.«

27. Bengtsson og Henningsen (1996), s. 37.

28. Jørgen Jørgensens personarkiv på Dansk Centralbibliotek for Sydslesvig, P 260-1.

29. Jørgen Jørgensen havde i foråret 1912 meldt sig som frivillig i København Amts Skyttekorps; derudover var han fra sit 17. år medlem af Amagerlands Skytteforening og deltog i skydningerne på dens baner ved Maglebylille. (Fra: Levnedsberetning til Ordenskapitlet, dateret Slesvig 1951; P 260-19).

30. Fra: Hфjskolebladet Nr. 5, Fredag den 1. Februar 1924.

31. Dagbogsnotater 19.10.1921, P 260-1.

32. Dagbogsnotater 22.10.1921, P 260-1.

33. Se f.eks. Rerup (1982), s. 366.

34. Dagbogsnotater 2.1.1923, P 260-1.

35. Dagbogsnotater 5.1.1924, P 260-1.

36. Dagbogsnotater, P 260-1.

37. Bengtsson og Henningsen (1996), s. $57 \mathrm{f}$.

38. Brev til faderens fødselsdag, dateret Hamborg 1.9.1923, P 260-1.

39. Beretning fra vandrelærerarbejdet 1924-25, formodentlig skrevet ultimo april 1925; P 260-5.

40. Bengtsson og Henningsen (1996), s. 102.

41. Dagbogsnotater 14.12.1924, P 260-1.

42. Dagbogsnotater 21.12.1924, P 260-1.
43. Beretning fra vandrelærerarbejdet 1924-25, formodentlig skrevet ultimo april 1925; P 260-5.

44. Udateret beretning, P 260-5.

45. Se mere herom i Jørn Hansen: »Idræt i grænselandet«, i: Jørn Hansen (red.): Idrcettens Steder. Idrætshistorisk Årbog 1997, 13. årgang. Odense Universitetsforlag 1998.

46. Afskrift af brev til Grænseforeningens sekretær, oberst Johs. Jørgensen, dateret Flensborghus 9.3.1926; P 260-5.

47. Bengtsson og Henningsen (1996), s. 102.

48. Jens Svendsen (red.): 50 års dansk skole i Slesvig by. Dansk Ungdomssekretariat 1980, s. 3 ff.

49. Bengtsson og Henningsen (1996), s. 102.

50. Brev til hjemmet, dateret Slesvig 6.7.1923; P 2601.

51. Niels Kjems: »Elevforeningen i Sydslesvig«, i: Franz Wingender og Sig. Kristensen: Dansk Ungdom i Sydslesvig. Th. Laursens Bogtrykkeri 1948, s. $93 \mathrm{f}$.

52. Dagbogsnotater 30.6.1925, P 260-1.

53. Dagbogsnotater 13.7.1926, P 260-1.

54. Ove Korsgaard: Kredsgang. Grundtvig som bokser. Gyldendal 1986, s. $53 \mathrm{ff}$.

55. Verner Bruhn: Det skave tra. Danske Gymnastikog Idrætsforeninger 1997, s. 11.

56. Franz Wingender og Sig. Kristensen: Dansk Ungdom i Sydslesvig. Th. Laursens Bogtrykkeri 1945, s. 88.

57. Valsbøls ungdomsforening Ydun havde taget navn efter den gamle danske forening Ydun, der blev dannet i 1877 som efterfølger for foreningen Enighed fra 1869, der var en kulturel forening. (Fra: J. N. Jensen: »Dansk Ungdomsvirke i Sydslesvig og Forbindelsen med Danmark 1864$1920 \ll$ i: F. Wingender og S. Kristensen (red.): Dansk Ungdom i Sydslesvig, s. 14.

58. Dagbogsnotater 7.2.1925, P 260-1.

59. Dagbogsnotater 24.5.1925, P 260-1.

60. Dagbogsnotater 26.8.1926, P 260-1.

61. Henrik Becker-Christensen: Det tyske mindretal $i$ Nordslesvig 1920-1932, bind I. Institut for grænseregionsforskning 1990, s.249 ff.

62. Dagbogsnotater 6.9.1925, P 260-1.

63. Dagbogsnotater 27.6.1926, P 260-1.

64. Beretning til (højst sandsynligt) Grænseforeningen over »Gymnastikkursus i Slesvig Vinteren 1926-27«, dateret Slesvig april 1927; P 260-5.

65. Se mere herom i f.eks. Ove Korsgaard: Kampen om kroppen. Gyldendal, 1982.

66. Niels Bukh selv mente iøvrigt ikke, at der var stor forskel på de behov, den arbejdende mand og kvinde havde på det gymnastiske område, og han 
underviste både mænd og kvinder (Korsgaard (1982), s. 236 ff.).

67. Jørn Hansen: »Gymnastik og sport - det borgerlige samfund og industrisamfundet? « i: Jørn Hansen og Kurt Klaudi Klausen (red.): Mellem kald og videnskab. Idrætshistorisk Årbog 1989, Bogforlaget DUO ApS, s. 20.

68. Se f.eks. Noack (1989), s. 356 f.

69. Fra Højskolesangbogen, her taget fra: Korsgaard (1997), s. 371.

70. Sporten blev jo - i modsætning til gymnastikken - opfattet som en udenlandsk importvare. Se mere herom i Jørn Hansen: »Gymnastik og sport - det borgerlige samfund og industrisamfundet? $\mathrm{i}$ : Mellem kald og videnskab. Idrætshistorisk Årbog 1989, Bogforlaget Duo ApS.

71. Johs. Stræde: Folkelighed og Fremtid. Poul Kristensens Forlag 1990, s. $157 \mathrm{ff}$.

72. Ove Korsgaard: Kundskabs-kaplфbet. Uddannelse i videnssamfundet. Gyldendal 1999, s. 198.
73. Ibid., s. 202.

74. Ibid., s. 203.

75. Ibid., s. 235.

76. Kosmopolitisk skal her ikke forstås som et overklassebegreb, der afsondrer den store majoritet fra at være med. Tværtimod slår Korsgaard til lyd for en fornyet integration af social udvikling og holdbar $\varnothing$ konomisk udvikling som en forudsætning for en menneskeværdig udvikling. (Korsgaard 1999, s. 235).

77. Stræde (1990), s. 166.

78. Niels Højlund: »Det folkelige i en international tidsalder«, i: Gymnastik og Idræetshøjskolen ved Viborg, Årsskrift 1999, s. 14.

79. Lynge Kjeldsen: »Folkeligheden i idrætten«, i: Gymnastik og Idratshøjskolen ved Viborg, Årsskrift 1999, s. 21.

80. Verner Bruhn: Det skave tra. Danske Gymnastikog Idrætsforeninger 1997. 